\title{
GCU
}

Glasgow Caledonian

University

University for the Common Good

\section{Exploring the contribution of rural enterprises to local resilience.}

\author{
Steiner, Artur; Atterton, Jane
}

Published in:

Journal of Rural Studies

DOI:

10.1016/j.jrurstud.2015.05.004

Publication date:

2015

Document Version

Author accepted manuscript

Link to publication in ResearchOnline

Citation for published version (Harvard):

Steiner, A \& Atterton, J 2015, 'Exploring the contribution of rural enterprises to local resilience.', Journal of Rural Studies, vol. 40, pp. 30-45. https://doi.org/10.1016/j.jrurstud.2015.05.004

\section{General rights}

Copyright and moral rights for the publications made accessible in the public portal are retained by the authors and/or other copyright owners and it is a condition of accessing publications that users recognise and abide by the legal requirements associated with these rights.

Take down policy

If you believe that this document breaches copyright please view our takedown policy at https://edshare.gcu.ac.uk/id/eprint/5179 for details of how to contact us. 


\title{
Exploring the contribution of rural enterprises to local resilience
}

Artur Steiner, Rural Policy Centre, Scotland's Rural College, Edinburgh Scotland, UK

Jane Atterton, Rural Policy Centre, Scotland's Rural College, Edinburgh, Scotland, UK

\begin{abstract}
The economic importance of the private sector, such as the contribution of businesses to Gross Domestic Product or to employment creation, is well recognised in research and policy. In the context of significant economic, social and environmental changes such as the economic downturn, public spending cuts, an ageing population and climate change, the broader social and environmental contributions of the private sector to local resilience have begun to be recognised by researchers and policy-makers. However, we lack a detailed understanding of the nature of, and motivations for, these different contributions.
\end{abstract}

This paper discusses the findings of a case study in South Australia which aimed to enhance our understanding of the role of private sector enterprises in local development and resilience. In particular, this article explores What, How and Why questions: What are the economic and social contributions of rural businesses to local resilience?, How are these contributions made? and Why do business owners make these contributions?

The findings reveal that rural businesses contribute to local resilience in both direct and indirect ways. Direct contributions include, for example, the creation of local employment and local product and service delivery. Indirect contributions can be understood as the knock-on effect or added value of primary business activities. For example, the provision of employment opportunities helps to reduce the risk of out-migration and depopulation. With reference to the concept of embeddedness, the study demonstrates the importance of the rural context in shaping the behaviour of rural business owners and encouraging them to operate in economically, socially and environmentally responsible ways. However, this is not a passive relationship; rural business owners have the motivation and resources to respond to specific local challenges, opportunities and characteristics, and to proactively and skilfully turn them into entrepreneurial opportunities. As such, they become part of the adaptation process, acting as agents of change in supporting rural resilience. This adaptation process contributes to enhanced community resilience which enables the modification of existing structures and the seeking of solutions to economic, social and environmental challenges.

KEY WORDS: Private sector businesses, local (economic, social, environmental) development, embeddedness, resilience, rural. 


\section{INTRODUCTION}

In many OECD countries, including Europe, the United States, Canada and Australia, policy-makers are increasingly seeking to support the resilience of communities and are indicating a need to increase selfreliance and sustainability at the community level (OECD, 2014). At the same time, however, rural communities are experiencing a period of rapid and ongoing economic, social and environmental transformation as a result of, for example, globalisation, economic downturn, public sector budgetary pressures, demographic ageing, and climate and environmental change (McManus et al., 2012; Schouten et al., 2012; Steiner and Cleary, 2014). All these factors influence the resilience of local communities, and their capacity to adapt to changing circumstances is increasingly important.

Literature indicates an increasing awareness of the need to develop rural policies that support the adaptive strategies of stakeholders that could be helpful in the governance of rural changes (Schouten et al., 2012). For instance, there is a rich body of literature describing public sector interventions as well as community-led initiatives for community development (for example see Herbert-Cheshire, 2000; Herbert-Cheshire and Higgins, 2004; Murray and Dunn, 1995; Skerratt and Steiner, 2013). This focuses on how to create stronger, more vibrant and sustainable communities, and frequently relates to community development projects funded through the state or managed and led by a community. Interestingly, the role of the private sector in developing community resilience is often either omitted or is discussed separately from the theme of community resilience.

It is possible, however, to find research evidence indicating that private sector organisations influence the life of rural communities and vice versa (see for example, Halseth and Ryser, 2006; Jack and Anderson, 2002; Martz and Sanderson, 2006) and, therefore, they can have a positive role in shaping the resilience of these places. This may be through direct impacts, including employment creation and service/product delivery (Eachus, 2014). Research evidence also indicates that rural businesses can offer in-kind contributions supporting their communities (Bruce et al., 2006) bringing indirect outputs for local development through the consequences that might arise from direct activities (Steiner and Atterton, 2014). For example, growing and diversifying the private business base can help to maintain the working-age population in a local area, contributing to demographic balance and sustaining the existence of other (public, private and third sector) services (e.g. schools, health care, community centres, shops). The private sector can, therefore, effectively utilise and develop existing resources which can enhance local resilience (Garnaut et al., 2001; Morrisson et al., 2012; PriceWaterhouseCoopers, 2007). At the same time, however, reductions in the availability of a range of business services in a local area can have a negative effect on community resilience (Halseth and Ryser, 2006; Steiner and Markantoni, 2014). Summarising these activities, Bosworth (2012) refers to the interrelatedness of rural businesses and their communities.

This study adds to the existing literature in this field by drawing together currently separate bodies of literature on resilience and embeddedness. The paper presents findings from a South Australia study of the contribution of rural businesses to their local communities. It begins by describing the concept of community resilience, followed by a literature review of the potential of private sector enterprises to 
support rural citizens and community resilience, including a discussion of the concept of embeddedness. This section highlights the importance of the rural context in shaping entrepreneurial behaviour, and vice versa, and the nature and extent of links between local business owners and their communities. The paper continues with a description of the methodology adopted in the study which involved in-depth interviews with business owners. The findings are then described, demonstrating the economic and social contributions of rural businesses to local resilience, including an analysis of how and why business owners behave as they do. While the focus is on their economic and social contributions, the paper also refers to the environmental concerns of rural businesses, as all three components - economic, social and environmental - are seen as essential for sustainable rural development (Glover, 2012; McMorran et al., 2014; Schouten et al., 2012; Wilson, 2012). The final section of the paper discusses the findings with reference to existing literature and highlights the key implications for policy-makers and researchers.

\section{COMMUNITY RESILIENCE}

\subsection{Definition and components of community resilience}

Defining community resilience is difficult as there is no agreement on what constitutes 'a resilient community' (Pendall et al., 2010; Skerratt, 2013; Wilson, 2012). While the term could be understood as the capacity of a system 'to absorb disturbance and re-organise while undergoing change so as to still retain essentially the same function, structure, identity, and feedbacks' (Folke, 2006, p.259), resilience is frequently seen as 'the existence, development, and engagement of community resources by community members to thrive in an environment characterised by change, uncertainty, unpredictability, and surprise' (Magis, 2010, p.402). The inevitability of change has become constant in modern community life and communities should mitigate the negative impacts of the changes they can anticipate and prepare to rapidly recover from those that cannot be mitigated (Plodinec et al., 2014). Community resilience suggests adaptation and proactivity in relation to stresses, changes, risks and challenges, and it relates to processes which enable a community to thrive, despite ongoing changes in the dynamic socio-economic and natural environment (Milman and Short, 2008). Ideally communities have the capability to anticipate risk, limit impact, and bounce back rapidly through survival, adaptability, evolution, and growth in the face of turbulent change (Eachus, 2014). This suggests interaction between structural forces and community agents in which community members are influenced by, but are also capable of influencing, their surroundings.

Literature in the field indicates that the key components of resilient communities include social aspects (Aked et al., 2010; Skerratt and Steiner, 2013; Steiner and Markantoni, 2014), economic characteristics (Leach, 2013; Norris et al., 2008; Noya and Clarence, 2009; Steiner and Atterton, 2014) and environmental features (Adger, 2000, 2003; Milman and Short, 2008). In order to develop more sustainable and resilient communities, it is necessary to possess adaptive capacity in all three of these dimensions (McMorran, et al., 2014; Norris et al., 2008); i.e. resilient rural communities embrace aspects of a viable local economy, a strong sense of belonging, social capital and engagement among residents and the quality of the local environment (McManus et al. 2012; Norris et al. 2008; Wilding, 2011). 
Wilson (2012) claims that economic, social and environmental capitals are considered to be the 'glue' that keeps the communities together and that each of these capitals is essential for communities to function well. McManus et al. (2012:28) highlight that 'resilience is not based on a single factor, nor is it related to economic issues or social issues separately'. Instead, economic, social and environmental issues are inter-related and resilience is dependent on all three simultaneously.

Consequently, a need to understand 'the balance of economic, social and environmental processes which shape the contemporary countryside and the interrelationships between these in particular localities' has been noted (Marsden, 1999, p.504). This section of the paper briefly describes the economic, social and environmental aspects of community resilience, before Section 3 focuses on the characteristics of rural business owners.

\subsection{Economic resilience}

The role of the private sector, and especially the entrepreneurial behaviour of small and medium enterprises (SMEs), is recognised globally as being important in regional, rural and remote development and in the sustainability of economies (Rola-Rubzen, 2011). Indeed, SMEs are considered the 'engineroom' of economic growth (Mazzarol et al., 2010). Through providing local employment, private enterprises contribute to enhancing economic resilience which incorporates aspects of income and employment, household assets and savings (Eachus, 2014). Better jobs, increased levels of entrepreneurship, positive social capital indicators, business performance and sustainability are all potential indicators of economic resilience (Noya and Clarence, 2009).

Research evidence suggests that community resilience is supported through a resilient local economy an economy with diverse businesses and employment opportunities (Steiner and Atterton, 2014). Overreliance on a single form of employment may create an inflated sense of security and resilience during economic boom but at times of economic downturn the same communities are extremely vulnerable (Eachus, 2014). In addition to diversity, community resilience depends on the volume of economic resources and the way they are mobilised (Magis, 2010; Norris et al., 2008). Access to a range of products and services is an important factor which enables people to carry out their daily activities effectively (Leach, 2013). Conversely, the absence of important facilities and support services within a community is detrimental to the quality of life of its members and may lead to the depopulation of the community.

A diverse and innovative economy recognises the interdependency of businesses and the community and focuses on how businesses and consumers can cooperate to keep money circulating within the community (Steiner and Atterton, 2014). According to Hegney et al. (2008, p.33) 'money spent and respent within the community builds more business, keeps more people employed, more services active in support of the community, and raises quality of life.' Local communities can act as supporters of local businesses by, for example, buying locally. Vibrant private businesses can help to retain and attract further investment in the area which, in turn, contributes to growing the private sector and increasing the resilience of local economies and the communities that depend on them (Noya and Clarence, 2009). The strong inter-linking of rural businesses with households and communities (Jack and Anderson, 2002; 
Oughton et al. 2003; Phillipson et al. 2004) means that the private sector can play a critical role in maintaining the health and vibrancy of communities.

\subsection{Social resilience}

While economic aspects of community resilience such as business diversity, employment and training opportunities, and the availability of a range of services and products in a local area, are perceived to be tangible and possible to observe, the social dimensions of resilience are less well understood (McMorran et al., 2014). As outlined in the previous section, the dynamic nature of social resilience is critical with the status quo not regarded as a meaningful goal and authors referring to the ongoing ability of a community to embrace change through social transformation and lifestyle change in order for it to survive and thrive (McManus et al. 2012; Skerratt, 2013).

Social resilience is frequently discussed with regard to the social aspects of human life. It is claimed that social resilience is an important indicator of social sustainability (Magis, 2010) and that the personal and collective engagement of community members is essential in order to thrive (Skerratt and Steiner, 2013). Activities that develop resilience should involve the entire community and, as such, social resilience is a participatory process in which community members take active roles in identifying solutions to their local challenges (Plodinec et al., 2014). This social participation and a sense of belonging created through cultural and social constructions along with local interactions, personal experiences and individual actions and beliefs, are important components of social resilience that can mitigate against rural community decline (McManus et al., 2012).

Social resilience is largely discussed in terms of social behaviour, social interaction and enhanced quality of life. At the heart of the notion of resilience there are aspects of local leadership as well as the ability of local actors to fit into a local area and to retain their social status within a community. Existing evidence indicates that the nature and extent of community networks influence aspects of social resilience. Well developed social networks and community events, meetings and local venues enhance local social interaction and help to improve the perceived quality of life. Moreover, rural communities characterised by strong social connections have an increased capacity to respond to disturbances (Schouten et al., 2012). Consequently, building community resilience requires the development of social capital and interpersonal links - both significant in increasing individual and community confidence, enhancing community capacity and motivation (Kilpatrick et al., 2011; McManus et al., 2012; McMorran et al., 2014; Taylor et al., 2014; Wilding, 2011).

Finally, components of social resilience include a sense of coherence, self-efficacy, social support and life events (Eachus, 2014). It has also been argued that resilience is about the ability of individuals and communities to learn from past experiences, being open, tolerant and inclusive, having a sense of purpose, being positive about the future, and having efficient leadership (Hegney et al., 2008). Resilience reportedly promotes greater wellbeing (Aked et al., 2010) by creating common objectives and encouraging community members to work together for the 'greater good'.

\subsection{Environmental resilience}


Community resilience is inextricably bound up with that of the environment in which a community is located. Human activities impact on the resilience of ecosystems and the relationship between the environment and communities is most clearly seen when the community is dependent on a single ecosystem or natural resource (Eachus, 2014). However, at the same time, the natural environment influences more subtle aspects of, for example, how people feel about and how they interact with their surroundings (Adger, 2000, 2003; Alberti and Marzluff, 2004; Milman and Short, 2008). The environment also has a role in attracting new residents and visitors, and building a sense of community pride. An attractive natural environment encourages outdoor activities and possibilities for connecting with nature (Aked et al., 2010) and frequently becomes a key tourist attraction. There is also a strong link between the natural environment and the physical and mental health of people - hence influencing community wellbeing. The tensions between maintaining (and improving) good environmental quality, increasing global food supply and mitigating and adapting to climate change have resulted in an increasing emphasis on developing low carbon economies and reducing greenhouse gas emissions. This agenda has opened up opportunities (and challenges) for communities, including in relation to the ownership and management of a variety of assets, such as renewable energy.

The economic, social and environmental components influencing community resilience are presented in Figure 1.

\section{Figure 1. Key components of community resilience}

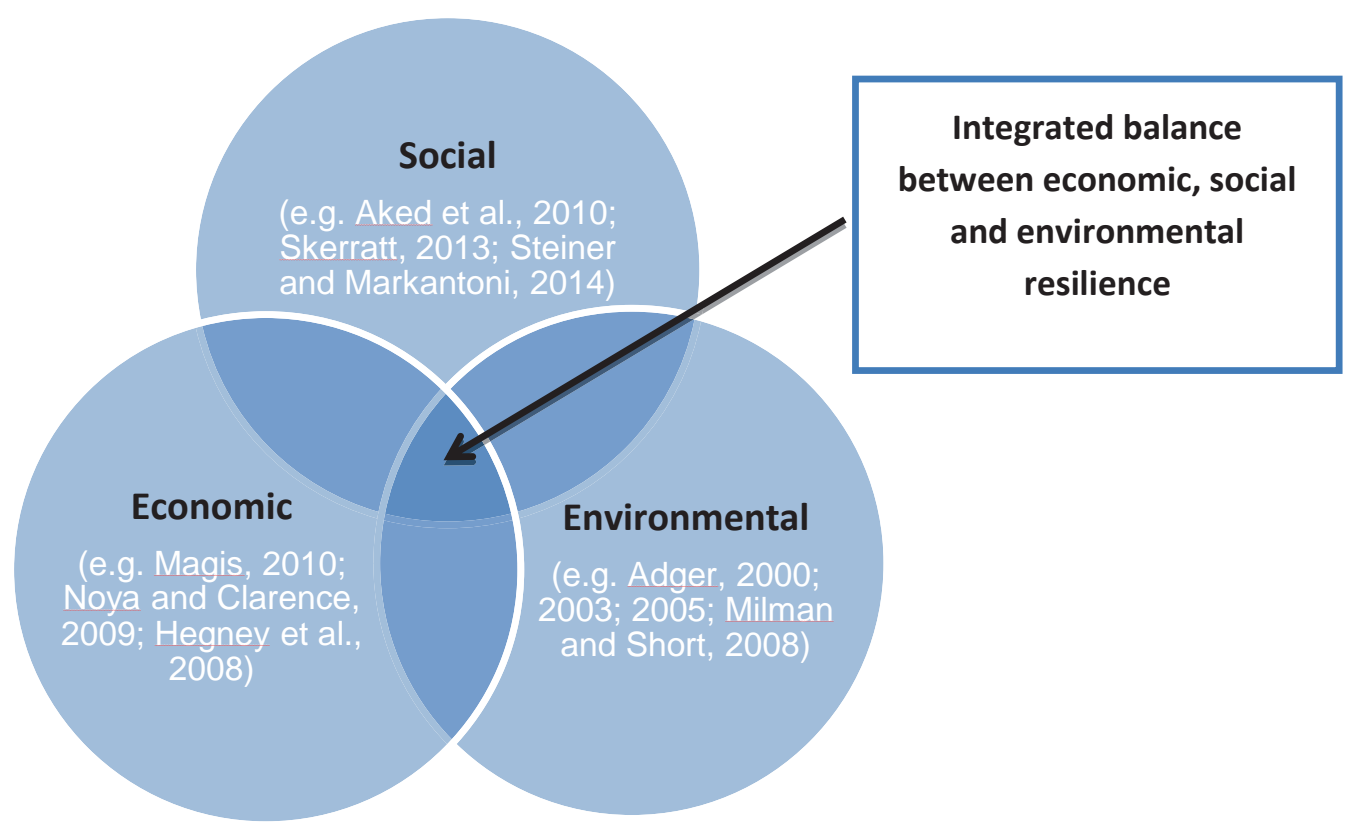

In general, places with strongly developed economic, social and environmental capital are likely to be more resilient than places where only one, or none, of these factors are present (Wilson, 2010) and the connection between economic, social, environmental aspects of rural life that promotes the resilience of 
rural citizens and their locations is critical (McManus et al., 2012; McMorran et al., 2014). Figure 1 demonstrates the need to integrate economic, social and environmental processes, and for communities to possess economic, social and environmental capitals, in order to create strong local community resilience. For instance, there might be communities with socially supportive structures but with no economic strength or potential for growth. Consequently, opportunities for the sustainable development of resilient communities might be hampered due to the lack of comprehensive approaches to community development. A balanced approach supporting integrated economic, social and environmental resilience is required.

Evidence suggests that resilience at the individual and community level is the key to managing significant stressors present in rural communities and that the individual resilience of rural business owners can assist in creating or enhancing resilience at the community level (Glover, 2012). The literature reviewed in this paper so far suggests that rural enterprises might be well placed to instigate, guide and lead processes enhancing community resilience. The final section of the literature review discusses the characteristics and motivations of rural business owners, providing the basis for the analysis of the data collected which addresses three key questions: (i) What are the economic and social contributions of rural businesses to local resilience?, (ii) How are these contributions made? and (iii) Why do business owners make these contributions?. Although not the main focus of this paper, given their importance in understanding overall community resilience, we also discuss the environmental activities and linkages of rural business owners.

\section{EXPLORATION OF RURAL BUSINESS ISSUES}

\subsection{Business activities and rural development}

Private sector enterprises are frequently the major employer in rural areas and, proportionally, they generate more jobs per head of population than private businesses in urban areas (Defra, 2005, Scottish Government, 2012) Diversified businesses not only help to provide a wide range of services and products but they also contribute to the creation of more stable local economies (Steiner and Atterton, 2014).

In various ways, rural businesses utilise available resources often contributing to their further development and positively influencing community resilience (Bosworth, 2012; Magis, 2010). Consequently, as Anderson et al. (2009) argue, the health of rural small businesses plays a significant part in rural economic and social wellbeing, including the quality of life of a place (Halseth and Ryser, 2006) as well as its economic viability and stability (Bowles, 2000). Business owners can provide leadership across a range of community groups (Bruce and Halseth, 2004) and can become a source for fundraising, through sponsoring specific local organisations or events (McDaniel, 2001).

A sense of serving their community is, therefore, integral to the behaviour of many rural business owners (Bosworth, 2012; Smith, 2008). Their behaviour is shaped and influenced, or co-constructed, by the rural business context within which they operate (Steinerowski and Steinerowska-Streb, 2012). It 
may also be shaped by the characteristics of their business (as described by Atterton, 2005). For example, locally owned firms are more likely to engage in their local community than firms which are owned externally (i.e. branch plant companies) (see for example, Courtney and Errington, 2000). Firms in peripheral locations are more likely to both rely on and serve local markets than firms in core locations, meaning that they are more strongly embedded in their local area and have a particularly visible presence locally (see for example, Gorton, 1999). Small firms have also been found to be more engaged in local markets than larger firms (see for example, Curran and Blackburn, 1994).

Moreover, as Jack and Anderson (2002) recognise, local embeddedness (i.e. the overlap of social and economic relationships and networks in a specific geographical area), which is argued to be particularly strong in rural locations, may open up opportunities for businesses, helping them to overcome some of the constraints of the rural environment. For example, the maintenance of strong ties with local suppliers which are grounded in strong social network relationships, may save a business having to source supplies from distant markets. This will also bring additional benefits to the local economy. However, it is also acknowledged that this strong embeddedness may over time result in negative impacts for businesses if they are tied into inflexible social relations (in short, they become overembedded), which may damage profitability and hinder positive change (Atterton, 2007; Oinas 1997).

\subsection{Rurality as a business context}

Rural locations are characterised by specific geographical features and although this geographical context defines rurality, Bosworth (2012) argues that we should avoid assuming that 'rural' is only a spatial term. Woods (2011, pp.40-41), for example, discusses 'the significance of networks, connections, flows and mobilises in constituting space and place and the social, economic, cultural and political forms and processes associated with them'. Rurality relates frequently to the relative inaccessibility of goods, services and opportunities for wider social interaction (Smailes et al., 2002); the latter being associated with the social production of rural places (Heley and Jones, 2012). In relation to business development, rural locations present challenges associated with small, widely dispersed clientele, limited human resources, physical, technical and economic barriers, and distance from service centres (Bryant and Joseph, 2001; Farmer et al., 2008; Schouten et al., 2012). Despite this (or possibly because of this) rural citizens are more likely to be socially orientated in their entrepreneurship than urban dwellers (Williams, 2007) and in recent years there has been a growth in community-run enterprises (Plunkett Foundation, 2011). It is suggested that the latter may be due, at least partly, to the strong social networks and embeddedness that are evident in rural communities (Aldrich and Zimmer, 1986; Atterton, 2007; Jack and Anderson, 2002; Woods, 2003, 2007, 2008). Rural citizens draw upon such traditional rural strengths, including high levels of trust and a strong sense of community and social cohesion (Shucksmith et al., 1996). Moreover, social networks are more dense in rural, as compared with urban, settings (Hofferth and Iceland, 1998), with the resulting outcomes of high levels of trust and active civic participation (Dale and Onyx, 2005). The existence of co-dependence, reciprocity and collective activity would also suggest that rural enterprises (and their owners) are socially aware (Granovetter, 2005; Kay, 2003; Shucksmith et al., 1996). The tendency of rural businesses is, therefore, to be more closely integrated into their local community (Reimer, 2006), generating loyalty and stability amongst their local customer base which may help to offset some of the limitations of the rural business environment (Chell 
and Baines, 2000). At the same time, however, as noted earlier, the extent of this local integration or embeddedness may vary between businesses with different characteristics (such as size, sector and ownership structure). Long-term business growth may be hampered if the social relations surrounding business activities serve to hold back those business activities (Oinas, 1997; Uzzi, 1996).

However, in entrepreneurial decisions, profit is often not the most important factor considered by rural business owners, who may be motivated by other considerations, such as growing the local economy and supporting local businesses. This characteristic is commonly associated with social entrepreneurs who are often portrayed as agents who engage in entrepreneurial activity that contributes to social capacity-building, with economic development as an adjunct rather than a primary focus (Austin et al., 2006; Mort et al., 2002; Roberts and Woods, 2005; Steinerowski et al., 2008b). It could be suggested, therefore, that as a result of the importance of stronger social networks in rural communities, rural entrepreneurship exhibits characteristics of social entrepreneurship, thereby enhancing its contribution to economic, social and environmental development. This is explored in the final part of the literature review.

\subsection{Rural businesses - much more than just profit making machines}

Business activities and entrepreneurship are associated with the 'discovery and exploitation of profitable opportunities' (Shane and Venkataraman, 2000, p.217). While many conceptualisations focus their attention on the economic functions of businesses (Acs and Audretsch, 2003; Schumpeter, 1934 in Austin et al., 2006), others take a more social perspective and argue that actors do not make decisions in a vacuum and are influenced by others in their environment (Atterton, 2007; Jack and Mouzas, 2007). This is the basis of Granovetter's (1985) original concept of embeddedness which is grounded in the assumption that economic action is enmeshed or integrated with social relations and institutions that affect its functioning (Oinas 1997). As Steinerowski and Steinerowska-Streb (2012) argue, the way that agents act depends on the specifics of the context in which they are immersed. In rural settings, the social context needs to be understood as being co-constructed through the adaptive capacity of agents, including rural business owners.

Indeed, there is a growing body of evidence suggesting that rural businesses are more than just 'money making machines' and that rural business owners extend their desires above and beyond pure profitability (Ateljevis and Doorne, 2000; Steinerowski et al., 2008a). More recent perspectives have even described business activities and entrepreneurship as a 'social undertaking' and one which must be understood within the context of social systems (Sarason et al., 2006, p.287). Hence, the literature refers to the unique, defining features of rural businesses that create different types of values both to local economies and to local communities (Bosworth, 2012), and suggests that the rural context shapes activities and the behaviour of rural business owners. These conceptualisations would appear to be based on the earlier writings of Granovetter (1985) and those who have developed his ideas (see for example, Atterton, 2007; Jack and Anderson 2002; Oinas 1997; Uzzi, 1996). This inter-relationship might also be thought of in a more active way for business owners who act as agents of change in shaping circumstances to their, and their community's, mutual advantage. 
Previous studies that present businesses as always seeking to 'beat and bury' the competition (Nalebuff and Brandenburger, 1997, p.28) and those that present businesses as friendly entities that always recognise the importance of partnerships, alliances and working together are both over-simplistic. Instead, a more common situation may be one of a combination of competition and cooperation, presented in the literature as "co-opetition" (Bonel et al., 2008; Walley and Custance, 2010). This represents a complex but potentially advantageous relationship between businesses. The complexity derives from the fundamentally different and contradictory logics of interaction that competition and cooperation are built on (Bengtsson and Kock, 2008). It seems that for rural businesses, which are often small and face the challenges of distance from core markets and limited local demand, co-opetition may be a particularly worthwhile strategy, drawing on the social capital and trust that is present in their strong local networks to co-operate, thereby helping to overcome the disadvantages of distance or limited markets for example, but still focusing on competing to provide their product or service. Indeed, work by Hingley et al. (2006) has applied this concept to the UK agri-food chain, for example. Ultimately business owners still need to make some money in order to survive, but co-operating to achieve economies of scale means that the success of one firm is fundamentally based on the success of other firms present in the locality.

This literature review has provided an insight into the components of the concept of resilience and argued that community resilience requires resources and adaptive capacity in all three of these dimensions. Private sector businesses have a critical role to play in delivering and enhancing this adaptive capacity, yet their role is often not explored in detail in the community resilience literature. Arguably, this role is both especially important and particularly likely in rural locations where social networks tend to be strong and the embeddedness of social and business networks especially evident, giving rural businesses access to the 'processes' through which to stimulate a positive chain reaction involving direct and indirect impacts. Building on this review of the literature, and drawing on empirical findings from South Australia, this study examines in detail the varied ways in which rural businesses contribute to local resilience. Three key questions guided the data collection and analysis phases, and these are reflected in the presentation of results: What are the economic and social contributions of rural businesses to local resilience? How are these contributions made? Why do rural business owners make these contributions? The answers to these questions help to identify useful avenues for further research in this area, and appropriate implications for policymakers seeking to enhance the resilience of rural communities.

\section{Methodology}

\subsection{Study context}

Australia is a large continent with a long coastline (Australian Bureau of Statistics, 2010) and with a population of 23 million, it is the 3rd least densely populated country in the world. However, Australia's developed market economy has a high rates of wealth and GDP per capita and a low rate of poverty (World Bank, 2014) and, despite the recent world economic crisis, Australia's economy has remained stable. Thus, although there are challenges brought about by remoteness and low population density, 
Australian businesses have performed well. This makes it a particularly interesting context in which to explore the contribution of rural businesses to community resilience.

In Australia, several different classification systems have been developed to define remoteness and rurality which take into account a number of factors and refer to the size of a community, distance from population centres, and access to services. The Australian Government, for example, identifies five geographical classifications including major cities, inner regional, outer regional, remote and very remote areas - these are presented in Figure 2 (Australian Government, 2014). While the majority of the Australian population lives in major cities and inner regional areas, 10 percent of Australians reside in outer regional, remote and very remote areas.

\section{Figure 2. Remoteness classification and geographical location of the study}

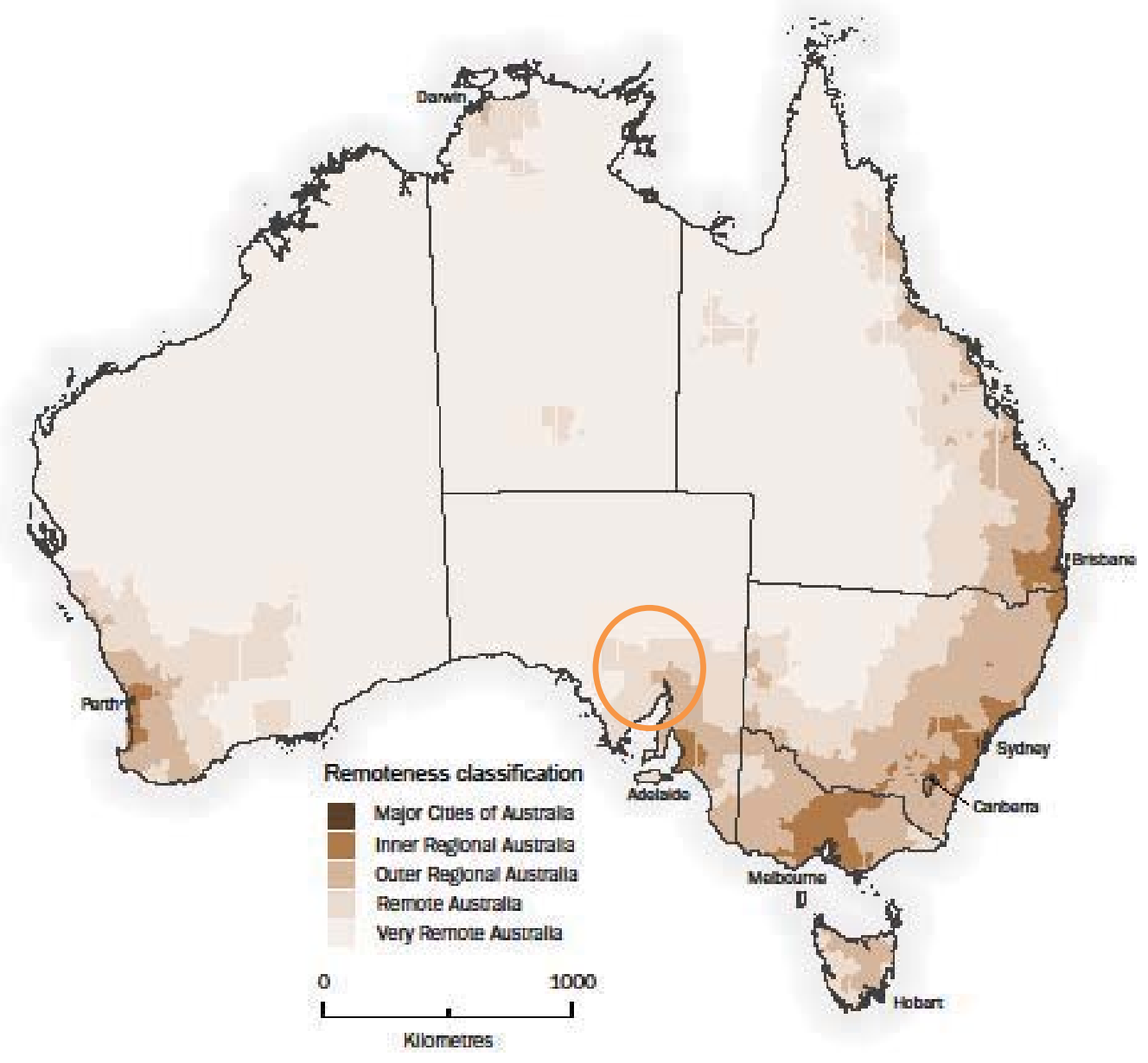

This research focused on the region of South Australia which is located in the southern central part of the country. This is a region that consists largely of remote and very remote areas (Figure 2). South Australia has maintained steady economic growth throughout the last decade, mainly due to mineral and energy resources that are becoming a more important part of the economy, and export industries including wheat, wool and wine (Government of South Australia, 2013). The region covers some of the most arid parts of the continent and a total land area of nearly one million square kilometres. The region 
is predominantly mixed agricultural with some heavier industry concentrated in larger regional centres (population 12,000-20,000) including Port Pirie, Port Augusta and Whyalla. With over 1.6 million people, the state comprises less than $8 \%$ of the Australian population and has a population density of 1.7 people per square kilometre. Although the population of South Australia increased between 2001 and 2013 by over a hundred thousand people, this growth was below the Australian average rate. The majority of South Australian people reside in the state capital, Adelaide, and many rural areas experience depopulation (Australian Bureau of Statistics, 2014). South Australia has a number of small (population 100-1000) and micro (population less than 100) communities. Businesses approached in this study were located in small communities. Four were located in rural areas that over recent years have experienced a decrease in population size and the remaining three were in areas that had experienced an increase in their population (Australian Bureau of Statistics, 2014).

\subsection{Research methods}

In-depth, semi-structured interviews were identified as being the most appropriate methods for use in this study, to gather detailed information about the type and impact of activities undertaken by rural enterprises. Interviews allow focus on the main topics and scope for elaboration, which is important for deeper understanding of "who", "why" and "how" questions (Hird, 2003; Saunders et al., 2003) that were being asked in this study. Interviewing also allows rapport to be built between the interviewer and interviewee, helping reveal information and issues which the interviewer may not have expected (Bryman and Bell, 2007). As noted by Kitchin and Tate (2000: 219) semi-structured interviews 'can provide a fuller and richer data set than might otherwise be gained through highly structured closed questions.' Also, interviews generate a high response rate (Gray, 2004) and enable a large amount of information to be generated covering a variety of topics (Oppenheim, 1992; Valentine, 2005). All these features were important for this study and this method was, therefore, seen as appropriate to find out how people behave in the setting under question, what meanings they give to their actions, and what issues concern them.

\subsection{Study sample}

A list of potential businesses to interview was generated as a result of a focus group organised with five members of Regional Development Australia (Far North) - RDA - which is one of 55 Regional Development Australia committees across the country that are tasked with regional social and economic development. The aim of the focus group was to access baseline information about rural businesses from the region and to discuss 'external' perceptions of the contribution of the businesses to local resilience. The focus group was also tasked with identifying businesses that would meet two criteria: (i) the identified enterprises had to be located within the south-east of the case study area of South Australia, and (ii) their positive contribution to economic, social and/or environment development of rural areas had to be recognised by RDA - hence, this represents a non-probability sample (Bryman and Bell, 2007). The focus of this research was then to explore what kinds of contributions they make and how and why they operate in this way.

From the generated list, ten businesses were selected and approached and seven of those gave their consent to be included in the study. This number was seen as sufficient for a study which aimed to 
pursue a depth, rather than breadth, analysis and was limited by time and financial constraints. Using a quota sampling strategy helped to produce a sample that reflected the population in terms of the relative proportions. Proportionally, the majority of businesses in Australia are SMEs (small enterprises represent $95.6 \%$ businesses, medium 4.1\%, and large 0.3\%; Australian Government, 2011) and this is reflected in our sample (see Table 1). Purposive sampling, which is suitable in situations when a researcher needs to reach a targeted sample quickly and where sampling for proportionality is not the primary concern, was used (Bryman and Bell, 2007). It was considered important to collect data from a range of businesses and, therefore, the selected businesses varied in terms of years in operation and profile. The detailed characteristics of businesses that took part in the study are presented in Table 1.

A topic guide for data collection and analysis was developed based on an international literature review of the theme under investigation, and discussions with local research staff. The questions aimed to explore the characteristics of businesses, their links with local communities, the role of the businesses in local (economic, social and environmental) development and, finally, the benefits and disadvantages that the organisation brought to local communities (examples of the questions are presented in Appendix 1). The guide was used to gather perspectives from rural business owners in South Australia thus the data presented in this article is self-reported.

Table 1. Business characteristics

\begin{tabular}{|c|c|c|c|c|}
\hline No. & Main activity & Size & Established & Scale \\
\hline 1 & $\begin{array}{l}\text { Manufacturing and } \\
\text { distribution of farm } \\
\text { machinery and } \\
\text { agricultural equipment }\end{array}$ & $\begin{array}{l}\text { Medium business; } \\
45 \text { employees + } \\
\text { approximately } 10 \\
\text { apprentices }\end{array}$ & 1987 & $\begin{array}{l}\text { International: } \\
\text { throughout } \\
\text { Australia, the US, } \\
\text { Canada, Central } \\
\text { America, Europe, } \\
\text { South Africa, New } \\
\text { Zealand }\end{array}$ \\
\hline 2 & $\begin{array}{l}\text { Pastoral tourism } \\
\text { business }\end{array}$ & $\begin{array}{l}\text { Micro/Small family } \\
\text { owned business } \\
\text { daughter employed (full } \\
\text { time) + Outback Helpers }\end{array}$ & $\begin{array}{l}\text { Pastoral business - } \\
\text { run by the fifth } \\
\text { generation in the } \\
\text { family } \\
\text { Tourism - } 1986\end{array}$ & $\begin{array}{l}\text { Local area, South } \\
\text { Australia; } \\
\text { occasionally } \\
\text { international visitors }\end{array}$ \\
\hline 3 & $\begin{array}{l}\text { Pastoral tourism } \\
\text { business }\end{array}$ & $\begin{array}{l}\text { Micro/Small family } \\
\text { business; } \\
3 \text { part time employees + } \\
\text { grey nomads }^{1}\end{array}$ & $\begin{array}{l}\text { Pastoral business } \\
\text { running for over } 100 \\
\text { years and tourism } \\
\text { running since } 2000\end{array}$ & $\begin{array}{l}\text { Local area, South } \\
\text { Australia; } \\
\text { occasionally } \\
\text { international visitors }\end{array}$ \\
\hline 4 & $\begin{array}{l}\text { Power and water } \\
\text { systems }\end{array}$ & $\begin{array}{l}\text { Small business; } \\
8 \text { people employed } \\
\text { including those full and } \\
\text { part time workers }\end{array}$ & $\begin{array}{l}\text { Merger of two } \\
\text { businesses in } \\
2011 / 2012\end{array}$ & $\begin{array}{l}\text { South Australia; } \\
\text { occasionally other } \\
\text { regions of Australia }\end{array}$ \\
\hline 5 & $\begin{array}{l}\text { Tourist orientated } \\
\text { bakery offering }\end{array}$ & $\begin{array}{l}\text { Small businesses; } \\
4 \text { permanent full time }\end{array}$ & 1997 & $\begin{array}{l}\text { Local area, South } \\
\text { Australia }\end{array}$ \\
\hline
\end{tabular}

\footnotetext{
${ }^{1}$ Grey Nomads are defined as people aged over 50 years, who adopt an extended period of travel independently within their own country. They travel by caravan, motor-home, campervan or converted bus for at least three months, but often up to several years, moving around Australia (Onyx and Leonard, 2005).
} 


\begin{tabular}{|l|l|l|l|l|}
\hline & $\begin{array}{l}\text { accommodation } \\
\text { facilities and a gift shop }\end{array}$ & $\begin{array}{l}\text { employees } \\
+2-3 \text { seasonal jobs }\end{array}$ & & \\
\hline 6 & $\begin{array}{l}\text { Labour intensive work } \\
\text { e.g. assembly and } \\
\text { packaging, mailing } \\
\text { bureau outside } \\
\text { maintenance, weeding, } \\
\text { litter collection, } \\
\text { cleaning, woodworking } \\
\text { unit }\end{array}$ & $\begin{array}{l}\text { Large business; } \\
487 \text { employees across } \\
\text { all divisions in the whole } \\
\text { state including those } \\
\text { full-time, part-time and } \\
\text { causal }\end{array}$ & 1952 & $\begin{array}{l}\text { Operates in South } \\
\text { Australia but some } \\
\text { customers are } \\
\text { international }\end{array}$ \\
\hline 7 & $\begin{array}{l}\text { Ice cream manufacturer } \\
\text { Medium business; } \\
\text { 60 employees including } \\
\text { those full-time, part- } \\
\text { time and causal }\end{array}$ & $\begin{array}{l}\text { 1923-1983 - a family } \\
\text { business; 1984 -2000 } \\
- \text { public company } \\
\text { between; 2001-2007 } \\
\text { private ownership; } \\
\text { 2008-current time - } \\
\text { joint private } \\
\text { ownership }\end{array}$ & $\begin{array}{l}\text { South Australia } \\
\text { distribute Australia } \\
\text { wide }\end{array}$ \\
& & & \\
\hline
\end{tabular}

As illustrated in Table 1, the size of businesses varied from micro (0-4 employees), small (employing less than 20 people), and medium (between 20 and 199 employees) to large enterprises (above 200 employees) (Australian Government, 2011). Some of the businesses were established over one hundred years ago, while others were created very recently. The business operations were also variable, with some delivering services and others developing products.

\subsection{Data collection}

Interviews were conducted over 40-90 minutes and were recorded, with consent, and subsequently transcribed. All interviewees were ensured anonymity in research outputs. In addition, field notes were collated and observations recorded. Qualitative analysis was mainly inductive although data was also compared against issues presented in the literature. All transcripts were initially read by the lead researcher and samples were also, independently, read by two other researchers (Thomas 2006). Emerging themes were discussed and consensus reached on an initial coding schedule which was used as a basis for systematic analysis of transcripts using N-Vivo qualitative data analysis software. Further iterations of analysis using N-Vivo occurred following feedback on initial coding. This approach elicited detailed information about the role of the private sector in the local development of South Australia. Quotes (with interviewee codes) are used in the write-up of the findings, in order to illustrate the interviewees' responses in support of the themes that the researchers identified.

\subsection{Reliability and validity and study limitations}

In order to ensure reliability, all interviewees were asked the same core questions (using the topic guide), which were used as the basis for the data analysis and the write-up of our findings (Blumberg et al., 2005). Moreover, all interviews were conducted and analysed by a single researcher suggesting that there are neither inter-interviewer nor inter-coder problems with reliability. In terms of study validity, while reaffirming the importance of contextual features in influencing the behaviour of rural businesses 
owners and based on a small sample of interviewees, we are able to draw out some over-arching findings of potential relevance to other regions beyond the case study region of South Australia (Bryman and Bell, 2007).

Triangulation of the data (literature review, followed by a focus group, followed by interviews) increased the credibility and validity of the study results. Although the literature review enabled the construction of a schedule for data collection, the exact categories describing the theme under investigation emerged through conducting interviews and during the data analysis, thereby ensuring greater accuracy. The key points identified in the focus group discussion were compared with data from interviews, thus verifying and extending observations made by the focus group participants helping to ensure confidence in the accuracy of the study findings.

It is recognised that face-to-face interviews can also have challenges and disadvantages. For example, they are often time consuming and expensive to conduct in a large geographical area (Bryman and Bell, 2007; Gray, 2004). There may be distortion by interviewees of the data collected through recall error, selective perception and a desire of respondents to present themselves in a good light relative to what they think the interviewer wishes to hear. Similarly it may be difficult for the interviewer to ensure that they remain objective and detached. Hence interviews may not be representative (Cloke et al. 2004). However, as Valentine (2005) argues, frequently interviews are not meant to be representative and often information which may not have been revealed through other methods is divulged. Moreover, while it is recognised that the small sample size imposes limitations on the generalisability of our findings, the study does support and add to the findings of other related studies contributing to the knowledge development in the field.

\section{FINDINGS}

In order to answer the identified research questions: (i) What are the economic and social contributions of rural businesses to local resilience? (ii) How are these contributions made? and (iii) Why do business owners make these contributions?, the findings presented discuss the contributions of rural enterprises to local resilience. The section describes the economic and social impact of rural businesses on local communities highlighting also the environmental issues associated with their activities. The importance of these three categories that emerged from the interview data was reaffirmed by the focus group discussion where there was identification that in addition to economic outcomes such as provision of employment and product/service delivery, rural businesses bring social benefits and tackle environmental challenges.

\subsection{The economic impact of rural businesses}

The study identified a number of economic benefits associated with rural business activities. Themes that were repeatedly highlighted in discussions with the interviewees and which refer to the positive 
impact of their business activities included: employment creation, product and service delivery, collaboration and networking, and added value.

\section{Employment creation}

The businesses interviewed varied in size from micro, small, medium to large businesses. Micro businesses often provide employment for family members. The data collected revealed that small businesses tend to rely on both full-time and part-time employees, as well as more seasonal or casual arrangements: 'we have 21 full-time, 5 are part-time and 22 are casuals...A lot of our employees are mums which is a second income to the family so if that wasn't available there would be more and more families in financial stress... we provide them with the second income stream that they need especially in today's environment' (B7). Although the scale and the type of employment depended frequently on the nature of the industry in which the businesses operate, the evidence shows that created employment is often significant in securing the financial situation of many families and encouraging people to stay in the locality and to continue using local services. This, consequently, helps those services to remain economically viable therefore securing their survival. Local businesses might, therefore, have an indirect knock-on impact on the availability of other local services: 'If we can continue to grow our business one of the opportunities is to employ more people. That means we either give local kids the opportunities to stay in their local area and maybe take on apprenticeships, or maybe it brings more families into the local community, the local district. And that will have positive benefits for schools and the service industries in this area' (B4).

\section{Product and service delivery}

Rural businesses provide essential services and products to local people and tourists, improving accessibility to and/or the quality of services and variety of services: 'there isn't anything else up this way for tourists... we're open 7 days a week from breakfast right through till five o'clock in the afternoon so people can get something to eat and stay... we give a service to the locals, if not to the locals then to their friends, and we supply and assist in the accommodation for all their functions' (B5). The availability of services locally can help to attract people to stay and live in or visit the area.

Moreover, being local can guarantee a good customer service: 'we very much emphasise that we're the local people because...people drive up from Adelaide, hang some solar panels on a roof and then disappear! And if there's a problem no one's going to come back' (B4). Thus, although not always the cheapest, businesses offer local, reliable services. It was highlighted that maintaining reputation is an important part of being local, and that reputation is built upon delivering high quality service. Moreover, seeing new business opportunities, business owners develop additional complementary services. For instance, in the tourism industry, in addition to accommodation, the business owners offer local food and drink specialities, souvenirs, and a range of products. This provides an additional source of income for the businesses, it helps to promote and sell local produce and, simultaneously, offers a better range of services.

\section{Collaboration and networking}


Interviewees discussed their collaboration with other businesses which brings mutual benefits: 'our production materials we're able to source in the local area... we do buy a little bit of stuff in from overseas but stuff that is not available in Australia' (B1). Using local suppliers was evident across many interviewees supporting local economies and helping to sustain existing services in the area. Thus businesses buy as much as they can from other local enterprises. In this case, geographical links and informal networks were influencing local business operation.

Our study indicates that although a level of networking across rural businesses exists it varies amongst individuals and sectors: 'all farmers all over Australia kind of know what's going on and share information and resources, don't see each other as competitors, which as soon as you step out of that into manufacturing or engineering everybody is a competitor and nobody wants to talk to you anymore' (B1). According to the respondents, working together can sometimes attract new customers. Interviewees referred to what they called 'cross promoting' and the importance of collaboration between local businesses which can enable business clusters to be built: 'we've all got together and called ourselves Station Stays SA... We collaborate locally...for instance down there [in the Restaurant] we have a 10\% discount card of theirs if people stay more than 5 nights...so you do that sort of value adding stuff and try and use your local businesses...Cross promoting-there's a lot of it done here...for instance...they can take a booking for us and actually take the money for it and then we pay them back $10 \%$ for taking that booking for us' (B2). This example shows that rural businesses utilise their informal networks to support each other and achieve better business results - described in the literature as coopetition. As noted, the balance between competition and cooperation depends on the type of industry. Still, co-opetition can help business owners to learn new skills from each other, develop relevant knowledge and, consequently, increase their financial profits.

\section{Added value and the multiplier effect}

Running a business frequently requires assistance from other businesses and this creates a positive knock-on effect (i.e. an added value that is not intentional) on the activities of other firms. This 'assistance' can relate to mutual trade (for example product or service acquisition) or to information exchange (such as joint promotion). Interviewees discussed the added value of their businesses and the benefits that they bring to the region. For instance, in the case of the tourism industry, providing accommodation might attract people to come to the area, stay a few days and spend money in local businesses. As such, there is a knock-on-effect: 'if you can get $X$ amount of people into a region and you can throw your product out there, and they might take it...it's all about keeping people in the region longer...there is opportunity there for people if you want to run a takeaway, or a coffee shop, or a deli. The opportunity is there to stay open and capture that money' (B3). Being located in the area can, therefore, help sustain other businesses. Thus, it is often the additional indirect impact of businesses that makes a contribution to local resilience.

There were also those who claimed that their businesses were essential for the sustainability of their areas: 'if we do decide to move to Adelaide, [this place] would be wiped off the map because we're the biggest employer...it has a major effect across the whole supply chain group...it's the whole multiplier effect' (B7). In rural communities with small populations, seemingly small decisions can have very far 
reaching consequences. Hence, it is important to acknowledge more than just a direct impact of business activities; it is crucial to see the bigger picture of the influence and added value that (often small) businesses have on the local economy and local communities as a whole, both in the short-term and over the longer-term.

\subsection{The social impact of rural businesses}

The findings show the crucial social contribution by rural businesses to rural and regional development. The key social benefits associated with the activities of rural businesses include: engagement with the community, promotion of the community and location, the creation of training opportunities and, finally, sponsorship and event support.

\section{Engagement with the community}

The study identified strong links between business owners and their communities. Respondents acknowledged their attachment to the location where they live and work. Many of them felt responsible for their rural communities: '[Our] family has been here...for a fairly long time, 130 years and so we're sixth generation here...so we see enormous value in being part of a small community, a strong community and so we see the value in contributing in trying to maintain that...as a business we...encourage our employees who work as volunteers in ambulance, or fire, or anything else. We support them and pay them while they're away working on that kind of thing just to encourage it to happen' (B1). The data in this study indicates that rural business owners frequently collaborate with their communities on non-business related matters, based on a sense of responsibility to their local communities: '[We've] been involved with the football club... we both were involved with the school council for 12 years...local government for 17 years of something... the RDA...we've been involved in various sporting organisations...I'm the one who goes to the regional tourism body at the moment. I'm passionate about Natural Resource Management so I'm on the group... we are on boards and committees that will bring things back down to happening here. Happening in our local community and to us that is very important' (B3). Hence, the business owners take different roles and are involved in local community and business associations, boards, councils, clubs and a variety of bodies that facilitate the life of a community: 'We're on so many different committees within communities...I'm the secretary of [one of the] Association which is just like a council because yeah we don't have a council...and you're always looking and trying to see what little things you can do to improve the town or assist the town...to raise some money' (B2).

Business owners felt a sense of responsibility for improving lives in their communities and they acted as role models and 'catalysts' for change: 'We're leaders ... when there is something that can happen in your district we are the ones who bring the people together to make it happen... We drag them along because for example... we had people saying oh we're not taking government money. They all did! Every single one of them! And they were fighting over how much government money they got and learnt how to manage all of those things' (B3). Business owners frequently felt a necessity to be involved in community projects associated with community development. 


\section{Promotion of community and marketing a geographical area}

Several business owners highlighted how their businesses attract people to visit the area and contribute to its increased recognition and popularity: 'if you look at the [the area] 10 years ago people knew about us but they didn't know a lot. And for us, our role was really pushing [our business] out there... we got it into the media, then the media managed to get it out to the customers. And the customers came to us and once they got to us we could push them to go to other places which then helped them to expand. And yeah...there's a lot of development in the area.' (B2) Hence, through developing and promoting their own businesses, business owners raise the profile of their locality and, simultaneously, can positively influence other businesses in the area that gain access to new customers. A number of business owners recognised the importance of promoting local settings and attracting international visitors: 'I always promote [our area] somehow, somewhere...certainly on the website we do but I never let the opportunity go by to say where we are and where we're from, how important it is to the local community about what we're doing' (B1).

It is important to emphasise that community members recognise and appreciate the positive contribution of local businesses. For instance, one interviewee discussed how winning a prize and bringing it to the community helped to build pride locally: 'we've been lucky enough to win a few awards over the last few years...my wife was in the supermarket after winning a national award 2 years ago and some of the little old ladies rushed up and gave her a hug. Thanks for bringing [our place] latest award back...so yeah there is quite a bit of town pride in the fact that the business is here' (B1). Respondents suggested that people frequently recognise the value of local businesses and, if possible, support them: 'we moved here 7 or 8 years ago...over the years they've come to be kind of proud of us...half of South Australia knows about us... whenever they have visitors they send them all here' (B5). Thus, rural businesses promote their geographical areas in the region, nationally and sometimes even internationally, and help to create a feeling of pride in the locality. Evidence of mutual respect between community members and businesses was, therefore, acknowledged.

\section{Training opportunities}

Interviewees discussed the important contribution they make creating training opportunities for people from the area which help to develop the skills of people. Thereafter they provide a job and therefore keep them in the area: 'we provide work experience opportunities for kids from local high schools throughout the district... and we probably take on a dozen or fifteen kids a year in work experience... We've developed a programme so the kids get some value out of ... when they're finished, they've got a document to take away [showing] the skills that they've learnt...of our workforce of 45 we have 10 apprentices...So every year we take on sort of 2 to 4 school leavers...So they see that as a pretty important contribution because these are kids that otherwise would have left home and gone somewhere else for employment and are now able to stay in the district, work' (B1). As noted, apprenticeships for young people bring mutual benefits to the apprentices who can get practical experience and the businesses that secure their future workforce. In addition to developing specific 
skills, young people learn how to be responsible and become familiar with the work ethic. Business owners said that through work it is possible to develop confidence and a can do approach amongst trainees. Moreover, some business owners acknowledged their use of backpackers who can work and, at the same time, earn some money.

One of the businesses offered employment and training opportunities to those who are disabled. The impact of this is more than just creating direct employment. It also creates a sense of belonging and supports the health and wellbeing of families of those who are disabled: '[we are] an employer of people with disabilities...if they didn't have us unfortunately they would have nowhere else to go. This is a form of income for them...it's also a place where they can mix with each other and it gives them a sense of belonging. It teaches them social skills and ethics. It's continuous training... we assist families here and families coming here know that if they do have a dependent with disabilities that there is somewhere for them to seek employment' (B6).

\section{Sponsorship and event support}

Business owners support their communities through sponsorship and donations: 'there is a corporate social responsibility element of supporting the local community, putting back into the local community' (B4). In addition to direct financial support, rural business owners highlighted that they donate their products and offer other forms of help facilitating local development: 'We support whatever groups there are... like we support a lot of sporting clubs in the region, the Tourism Board...if they have events on they will ring us up and we will donate some products... We also sponsor [two local festivals]...if schools have got something on we'll help them out with a donation of products' (B7). Moreover, some interviewees indicated less tangible support associated with resolving problems or giving advice: 'contributions we make whether they be in cash sponsorship or whether its work that we will do, we can turn our expertise to solving a local problem and we'll do that at no charge and sometimes it's a significant contribution for a small community' (B1).

Business owners felt that it was necessary to support community events as otherwise many of those local events would not take place. Consequently, the study found evidence of social responsibility amongst rural businesses which see their role in supporting communities through direct financial support and indirect help that can facilitate development of local events and/or initiatives.

\subsection{The environmental impact of rural businesses}

The interviews also provided evidence of the environmental impact of rural businesses, in addition to the economic and social benefits already discussed. These included two key themes associated with environmental awareness and natural environment protection. While some of issues presented by business owners related directly to a particular business profile and could be perceived as having an unintentional positive effect on the environment, others related to the conscious decisions of business owners. 


\section{Environmental awareness}

Appreciation of the land and environment was indicated by many business owners in addition to running a business: 'the pastoral business has organic accreditation... and the tourism business has advanced eco-accreditation... we're not here to rape and pillage the land, our family has been here for 125 years so we have to learn how to improve our environment rather than degrade it' (B3). Hence, the study identified the respect and gratitude of business owners towards the land that feeds them which can relate to tradition and a historical place attachment. In addition, future environmental sustainability is also important for those running businesses in rural areas and this was indicated in many interviews: 'We consider the type of vehicles we have so for example, we have very limited motorbikes because they have those big knobbly tyres just driving over a reasonable surface dig it up. Now you can't do that in this country because it doesn't repair, it might be 11 months before there is enough rain to wash out those tracks. So we consider very carefully if we have that type of vehicle...the 4 wheel drive is a sustainable vehicle. It's a soft wide tyre and it doesn't leave those huge marks. So we're all about sustainability' (B3).

Respondents talked about their motivation to protect the natural environment and demonstrate environmental awareness in many different ways. For example, several business owners referred to the importance of recycling or taking conscious business decisions that help in becoming environmentally friendly: 'we sponsored the Adelaide Zoo...and after having a few meetings with them they were talking about the impact of palm-oil on the orang-utans and the tigers and the destruction of the rainforest in Asia...so we made the decision to review all our ingredients and become a palm oil free company...And our waste water we pump to the council ponds and that goes to their grounds, the parklands in the township' (B7).

\section{Natural environment protection}

Interestingly, some businesses tackle environmental issues directly through their business activities: 'our business is very much focused on two important areas of the environment, in energy and water... we're seen as assisting with innovative projects, people can see that their waste water is being recycled and used, it's a resource, they're going to have a nice green sporting oval because they've now got access to this recycled water' (B4). Innovative environmentally-friendly solutions introduced by local businesses can facilitate the production of renewable energy and tackle issues associated with water supply which is one of the most significant challenges in many rural places in Australia. It was indicated that while some projects are contracted and run in collaboration with local governments, other initiatives are cofinanced through the governmental schemes or are financed privately. For instance, one of the business owners referred to his collaboration with the council and a contract that involves collecting illegally dumped rubbish and to look after the parks and gardens. These are important activities which have an impact on the natural environment and the quality of life in the countryside.

Finally, some business owners referred to indirect environmental benefits. For instance, the provision of local products and services translates into lower fuel consumption and a reduced carbon footprint by those potentially travelling to access them: There's a fair range of products that we have on sale. For 
example, emergency things like bread, milk and ice, so that it actually saves them [customers] a hundred $\mathrm{km}$ round trip to get those sorts of things (B3). A similar argument was used by those involved in the tourism industry who claimed to offer alternative to distant holiday destinations; without local offerings, some would have to travel a long distance to find a holiday spot. Thus there are also less tangible aspects that need to be considered when reviewing the role of businesses in local development.

\subsection{Summary of findings}

In order to summarise the emerging patterns and inform our discussion in section 6, firstly we present Table 2 which highlights the different contributions that rural businesses bring to their local communities.

Table 2. The economic, social and environmental contributions of rural businesses

\begin{tabular}{|l|l|l|}
\hline $\begin{array}{l}\text { Category of } \\
\text { generated benefits }\end{array}$ & Type of contribution & Example \\
\hline Economic & Employment creation & $\begin{array}{l}\text { New local jobs, diversity of jobs (e.g. provision } \\
\text { of part-time, full-time, seasonal) }\end{array}$ \\
\cline { 2 - 3 } & $\begin{array}{l}\text { Product and service } \\
\text { delivery }\end{array}$ & $\begin{array}{l}\text { Delivery of products/services that otherwise } \\
\text { would not be locally provided (e.g. } \\
\text { accommodation, groceries, engineering } \\
\text { services) }\end{array}$ \\
\cline { 2 - 3 } & $\begin{array}{l}\text { Collaboration with other } \\
\text { local and regional } \\
\text { businesses }\end{array}$ & $\begin{array}{l}\text { 'Cross-promotion' and mutual support; trading } \\
\text { and exchanging information (e.g. distribution } \\
\text { of discount cards encouraging to visit other } \\
\text { local businesses) }\end{array}$ \\
\cline { 2 - 3 } & $\begin{array}{l}\text { Added value and spill over } \\
\text { effects }\end{array}$ & $\begin{array}{l}\text { Knock-on or 'domino-effect' of business } \\
\text { activities (e.g. generated jobs encourage young } \\
\text { people to stay in the area) }\end{array}$ \\
\hline Social & $\begin{array}{l}\text { Engagement with } \\
\text { community }\end{array}$ & $\begin{array}{l}\text { Being an active member supporting a } \\
\text { community in a range of matters (e.g. } \\
\text { membership in a community council board) }\end{array}$ \\
\cline { 2 - 3 } & $\begin{array}{l}\text { Promotion of community } \\
\text { and location }\end{array}$ & $\begin{array}{l}\text { Building the profile of a community and its } \\
\text { recognition (e.g. receiving a national prize) }\end{array}$ \\
\cline { 2 - 3 } & Training opportunities & $\begin{array}{l}\text { Provision of skills development programmes } \\
\text { (e.g. work experience and apprenticeships for } \\
\text { young people) }\end{array}$ \\
\cline { 2 - 3 } & Sponsorship, event support & $\begin{array}{l}\text { Donations and support offered to local } \\
\text { community groups (e.g. football club) }\end{array}$ \\
\cline { 2 - 3 } & $\begin{array}{l}\text { Protecting natural } \\
\text { environment }\end{array}$ & $\begin{array}{l}\text { Acting in an eco-friendly manner (e.g. through } \\
\text { recycling) }\end{array}$ \\
\hline $\begin{array}{l}\text { Developing eco-friendly solutions (e.g. water } \\
\text { recycle, production of solar energy) }\end{array}$ \\
\hline Environmental
\end{tabular}

Table 2 helps to answer the question: What are the economic and social contributions of rural businesses to local resilience? Moreover, the table provides additional information about the environmental contributions of rural businesses to developing rural resilience. In addition, and before we move to the 
following discussion section, Table 3 reveals answers to Why and How questions: Why and how are these contributions made?

Table 3. The contribution of rural enterprises to local resilience - exploration of What, How and Why questions

\begin{tabular}{|c|c|c|}
\hline WHAT & HOW & WHY \\
\hline \multirow{2}{*}{ :U } & $\begin{array}{l}\text { Direct e.g. } \\
\text { - employment creation (e.g. 'we have } 21 \text { full- } \\
\text { time, } 5 \text { are part-time [employees]' - B7) } \\
\text { - service delivery (e.g. 'we give a service to the } \\
\text { locals' - B5) }\end{array}$ & $\begin{array}{l}\text { Direct e.g. } \\
\text { - To increase financial income for the area (e.g. } \\
\text { 'We would like to make it like a destination point } \\
\text { eventually, have a café where people can come in } \\
\text { and taste our whole range of ice-creams, look at } \\
\text { the way the ice-cream is made, the process, so } \\
\text { make it a destination point for people to come } \\
\text { and visit the township ... and that would promote } \\
\text { the region and increase the amount of money } \\
\text { that's coming into the area'- B7) }\end{array}$ \\
\hline & $\begin{array}{l}\text { Indirect e.g. } \\
\text { - Collaboration and networking with other } \\
\text { businesses (e.g. 'our production materials } \\
\text { we're able to source in the local area' - B1) } \\
\text { - Added value and knock-on effect (e.g. 'if we } \\
\text { do decide to move to Adelaide, [this place] } \\
\text { would be wiped off the map because we're } \\
\text { the biggest employer' - B7) }\end{array}$ & $\begin{array}{l}\text { Indirect e.g. } \\
\text { - To maintain local economic development } \\
\text { 'We're going to put another person on, there's } \\
\text { another vehicle, the vehicle has been bought } \\
\text { from the local car dealer, it will be maintained by } \\
\text { the local car dealer, it will get its fuel from the } \\
\text { local fuel agent, so we are contributing to the } \\
\text { local economy in that sense' - B4) }\end{array}$ \\
\hline \multirow{2}{*}{$\begin{array}{l}\overline{\frac{\pi}{2}} \\
\text { 요 }\end{array}$} & $\begin{array}{l}\text { Direct e.g. } \\
\text { - Sponsorship (e.g. 'there is a corporate social } \\
\text { responsibility element of supporting the local } \\
\text { community, putting back into the local } \\
\text { community' - B4) } \\
\text { - Training opportunities (e.g. '[we are] an } \\
\text { employer of people with disabilities... it's also } \\
\text { a place where they can mix with each other } \\
\text { and it gives them a sense of belonging. It } \\
\text { teaches them social skills and ethics - B6) }\end{array}$ & $\begin{array}{l}\text { Direct e.g. } \\
\text { - To be part of social networks (e.g. '[Our] family } \\
\text { has been here on this farm...for } 130 \text { years and so } \\
\text { we're sixth generation here...so we see enormous } \\
\text { value in being part of a small community, a } \\
\text { strong community and so we see the value in } \\
\text { contributing in trying to maintain that' - B1) }\end{array}$ \\
\hline & $\begin{array}{l}\text { Indirect e.g. } \\
\text { - Engagement with community (e.g. '[We've] } \\
\text { been involved with the football club... the } \\
\text { school council...local government... we've been } \\
\text { involved in various sporting organisations... we } \\
\text { are on boards and committees that will bring } \\
\text { things back down to happening here' - B3) } \\
\text { - Promotion of community (e.g. 'over the } \\
\text { years they've come to be kind of proud of } \\
\text { us... half of South Australia knows about us' - } \\
\text { B5) }\end{array}$ & $\begin{array}{l}\text { Indirect e.g. } \\
\text { - To support community development (e.g. 'If we } \\
\text { can continue to grow our business one of the } \\
\text { opportunities is to employ more people. That } \\
\text { means we either give locals kids the opportunities } \\
\text { to stay in their local area and maybe take on } \\
\text { apprenticeships, or maybe it brings more families } \\
\text { into the local community, the local district. And } \\
\text { that will have positive benefits for schools and } \\
\text { the service industries in this area' - B4) }\end{array}$ \\
\hline 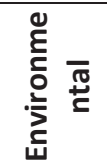 & $\begin{array}{l}\text { Direct e.g. } \\
\text { - Environmental awareness (e.g. 'we made } \\
\text { the decision to review all our ingredients and } \\
\text { become a palm oil free company' - B7) }\end{array}$ & $\begin{array}{l}\text { Direct e.g. } \\
\text { - To maintain environment sustainability (e.g. } \\
\text { 'the philosophy... is that we have to be } \\
\text { sustainable into the future and we're not here to }\end{array}$ \\
\hline
\end{tabular}




\begin{tabular}{|c|c|}
\hline & $\begin{array}{l}\text { rape and pillage the land, our family has been } \\
\text { here for a } 125 \text { years so we have to learn how to } \\
\text { improve our environment rather than degrade it' } \\
\text { - B3) }\end{array}$ \\
\hline $\begin{array}{l}\text { Indirect e.g. } \\
\text { - Natural environment protection (e.g. 'we're } \\
\text { seen as assisting with innovative projects, } \\
\text { people can see that their waste water is being } \\
\text { recycled and used, it's a resource' - B4) }\end{array}$ & $\begin{array}{l}\text { Indirect e.g. } \\
\text { - To reduce carbon footprint (e.g. There's a fair } \\
\text { range of products that we have on sale... so that } \\
\text { it actually saves them [customers] hundred } k \\
\text { round trip to get those sorts of things' - B3) }\end{array}$ \\
\hline
\end{tabular}

Tables 2 and 3 provide a summary of the findings that help to answer our key research questions. Section 6 of the paper brings together the evidence and refers back to the literature already reviewed to demonstrate how businesses in this rural area of South Australia contribute to local resilience.

\section{DISCUSSION}

This paper has explored the contribution of rural enterprises to local resilience in an Australian context. In order to do that, we (i) reviewed the economic and social contributions of rural businesses to local resilience and (ii) identified how and why these contributions are made. Additionally, given the importance of taking a broad approach to defining resilience, we show how rural businesses contribute to environmental aspects of rural resilience.

In economic terms, private enterprises create different forms of employment, including for young apprentices or the disabled, contribute to product and service delivery (often built on securing a loyal customer base), and develop local networks and collaborations, often in place of or alongside competitive relationships. Working together with other businesses can help to generate positive multiplier effects and bring local value added. These direct contributions can all help to reduce the risks of depopulation and out-migration. Interviewees noted that private ownership is often the only way to sustain some businesses and, therefore, to maintain locally-based services, thereby helping to create and maintain resilient communities. These direct outcomes are supplemented by less tangible social and environmental outputs.

Often it was what could be termed 'social' motivations driving the activities and attitudes of business owners, who frequently feel a sense of responsibility for their communities and, consequently, engage or become embedded in community life in various ways. This might include joining committees, encouraging employees to volunteer for local service provision, and supporting local sports and cultural clubs. Businesses also often provide direct sponsorship for local events and product donations for the promotion of a local area and offer support and advice in solving local problems. This evidence supports the findings of previous research (see for example Atterton, 2007; Jack and Anderson, 2002), which demonstrated the close inter-linking of business and social relations within rural communities.

Thus, despite the many responsibilities associated with running a business, rural business owners also devote resources to getting involved in other community activities, offering their time, knowledge, skills and expertise as they wish their communities to be resilient. Consequently, owners of rural businesses 
are often perceived as positive community leaders who motivate community members and create new solutions to existing challenges in order to enhance the quality of life of rural citizens.

The evidence collected here also suggests that rural businesses are environmentally aware; for example, they acquire eco-certificates, recycle and, additionally, offer innovative solutions to generate renewable energy or restore water. Owners of rural businesses claimed that they respect the land on which they work and live and that they are concerned with its sustainability. This happens through both conscious decisions (e.g. using production ingredients that do not harm the natural environment) and as a consequence of their locally focused service/produce provision (which helps to reduce the number of long journeys required and, therefore, their carbon-footprint) - both bring a positive impact on the natural environment.

Our study demonstrates that context matters as it fundamentally influences what business owners do and how and why they do it. Although issues such as a low population density and a widely dispersed clientele, inaccessibility of goods and services and limited resources, represent common challenges influencing the resilience of communities and the activities of business owners across rural areas, there are more specific local features that need to be considered when discussing contextual aspects. In our study, the rural context of South Australia created unique challenges and opportunities for local business owners. For instance, the dry climate and shortage of water triggered the creation of an entrepreneurial solution to these challenges, through the distribution of water recycling equipment. The closure of a publicly owned company led entrepreneurial individuals to take over the firm thereby securing employment in the region and contributing to its overall sustainability. Over the years, owning a significant farm landmass led to the development of machinery and agricultural equipment now distributed around the world.

These examples emerged in the case study area of rural south-east South Australia and they show how rural business owners can positively influence rural resilience, drawing on the specific opportunities and challenges of the contexts in which they are located. Business owners engage with their communities as a result of their local networks and their recognition of aims other than business profitability thereby supporting their overall social development (e.g. through organising local events) and acting as critical agents of change. This relationship between context, entrepreneurial behaviour and community resilience is presented in Figure 3, where business owners are shown as active agents of change shaping the characteristics of the context in which they are located (i.e. the structure) to help the creation of more resilient communities.

Figure 3. Relationship between context, entrepreneurial behaviour and community resilience 


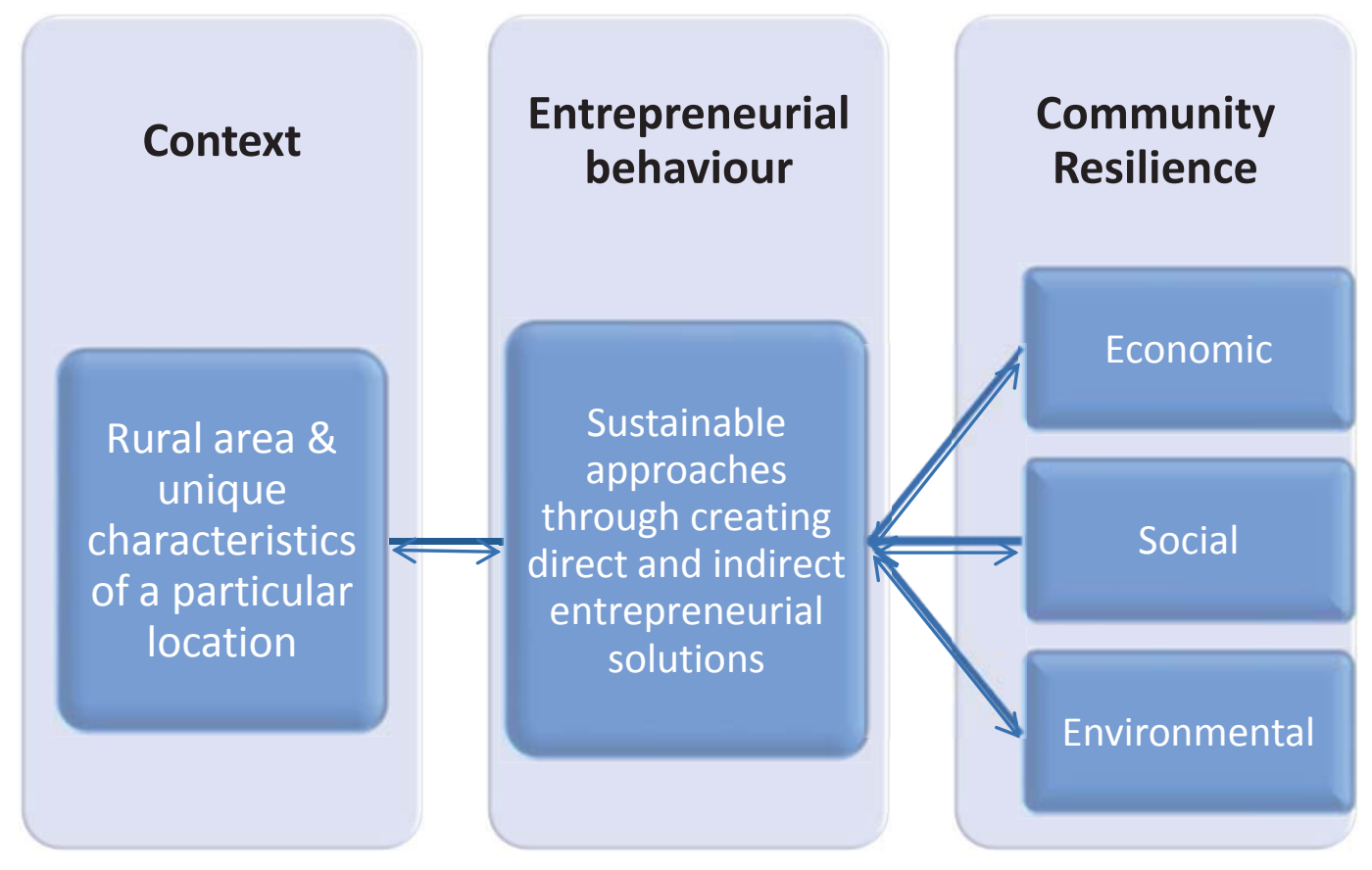

Our findings suggest that rural context shapes, influences and co-constructs the behaviour of rural business owners. Rural business owners are or become a part of the community and, therefore, follow established roles and patterns. Consequently, values associated with a strong sense of community, strong networks and ties, mutual trust and active civic participation (Anderson and Jack, 2002; Atterton, 2007; Dale and Onyx, 2005; Granovetter, 1985; Hofferth and Iceland, 1998; Reimer, 2006; Shucksmith et al., 1996) become a component of business behaviour and etiquette which is more socially orientated than traditional definitions of entrepreneurs might allow (Steinerowski and Steinerowska-Streb, 2012; Williams, 2007).

Rural business owners often try to avoid direct competition with other local businesses, rather delivering services/products that are complementary to, or not currently delivered by, local businesses. Hence, through utilising social connections and being 'socially aware' rural business owners influence the economic dimensions of their activities and, for example, replace competition with co-opetition. Although this is a business tactic that helps to secure their place in the market, this co-opetition is more than this as it supports the sustainability of all local businesses maintaining employment opportunities as well as the availability of a wider range services and products. This helps to understand Why the entrepreneurial approach of rural business owners is socially- or community-orientated and contributes to local resilience. Their interrelationships with the context in which they operate encourage rural business owners to behave in economically, socially and environmentally responsible ways. They actively identify (direct and indirect) ways in which they can build on local advantages and attempt to overcome local constraints, turning them into advantages and thereby enhancing resilience.

Finally in relation to the How question, the evidence has identified that we need to recognise the broad range of contributions that rural enterprises make to local resilience, including the 'chain reaction' of 
both direct and indirect impacts. Hence, rather than only looking at the direct outcomes of business activities, it is essential to recognise the possibly less tangible but equally important indirect inputs and added value of rural businesses. All of these impacts are influenced by the features of the rural and local context in which the business operates, as a result of the embeddedness of business owners in their surroundings.

It seems, therefore, that the comparison of rural business owners to social entrepreneurs might not be entirely accurate when describing their activities and actions. In addition to being motivated to maintain both business and social or community concerns, rural business owners find that their behaviour is shaped by, and indeed shapes, the rural context in which they operate hence their contributions to enhanced community resilience.

Through the case study work in rural South Australia the evidence has established that in terms of the what, business owners make a variety of important contributions to rural resilience, including direct provision of jobs and the indirect maintenance of the local population. In terms of how, they make these contributions through the embeddedness of their economic relationships in strong social structures and their interrelationships with the content in which they operate. Finally, in terms of why, they are often motivated both by concerns to maximise profit - or at least to make a living - to support their local communities.

\section{CONCLUSIONS}

Due to their varied economic, social and environmental contributions, private sector businesses play a critical role in enhancing the positive functioning of local rural economies and the development of resilient communities. They are proactive agents of change, although aspects of their local context, including the actions of other business owners, shape their actions in seeking to make the most of the opportunities and challenges they face. In this way, there is a dynamic, adaptive relationship between business owners, and between business owners and their local community, which re-shapes existing structures and finds solutions to economic, social and environmental challenges.

A number of implications can be drawn for policy-makers seeking to support rural businesses and community resilience. For instance, policy-makers need to recognise that they may seek a variety of objectives through their business activity, including maintaining the business, but also supporting wider community-related objectives. In short, profit maximisation may not be their sole motivation. Policies and initiatives which at least recognise, and ideally which seek to build on, these multiple roles should be encouraged. Although these broader impacts may be difficult to capture quantitatively, they are very important in demonstrating the holistic contributions of rural businesses, and include sustaining local services, maintaining the local population, reducing negative climate impacts of long car journeys through providing local services and employment, and sustaining local community events, social capital and a strong sense of local identity. Holistic, cross-sectoral approaches are required to maximise these benefits for businesses and communities alike. Specific business support initiatives might include the 
promotion of networking activities to encourage co-opetition, although these need to be clearly tailored to the local context in which businesses are operating.

As the private sector has a critical role to play in enhancing rural resilience, it is critical that it is engaged in local third sector and community initiatives. Often such initiatives omit private sector actors, or engage them only in a limited way, and this needs to change in order to ensure that they can maximise their positive impacts locally.

This study contributes to the existing body of knowledge in the field of rural businesses and their links to community resilience. It has brought together two currently separate areas of literature on resilience and embeddedness, and supports the findings of previous research which have demonstrated that businesses have an important role in enhancing local resilience. They are able to utilise available economic, social and environmental resources in order to bring both private and community benefits. For geographers and other social researchers, this study reinforces earlier evidence indicating that 'rural' is not only a spatial term - it also relates to other social aspects such as the entrepreneurial behaviour of rural business owners. In response to the challenges of operating in a rural context and building on their recognition of broader benefits and outcomes, business owners are expected to, and indeed do deliver, more for their communities, thereby contributing to overall (as opposed to purely personal) development and local resilience. There are strong interdependencies between rural communities and the activities of rural business owners - both needing each other to survive and thrive. The rural context clearly influences the behaviour of rural business owners, yet it is more than this as they have the skills, knowledge and breadth of aims, to identify and implement solutions to very unique challenges.

This case study of South Australia could form the basis for further in-depth work in rural communities elsewhere in Australia and beyond, to further explore the contributions of local businesses. This work could involve a large-scale sample and, therefore, focus on drawing out differences between businesses operating in different sectors, or businesses of different sizes, ages or ownership structures. Such work is arguably of growing importance due to the ongoing budgetary pressures faced by the public sector, which is often a major employer in rural communities, and the increasing emphasis on the private (and third) sector to 'fill the gap' and contribute positively to the sustainability of rural communities. 'Placebased' research work (Woods 2007) which combines qualitative and quantitative data to better demonstrate the holistic impacts of rural businesses and how they can be grown through policy and practical interventions, could be undertaken in a variety of different regional contexts. Qualitatively it would be interesting to explore how the attitudes and behaviours of rural business owners towards their communities may change over time. For example, exploring whether there is a threshold at which business owners choose, or perhaps are forced, to change their behaviour and reduce their interactions with their local community in order to focus on the business. The alternative perspectives of owners with different characteristics would also be interesting to investigate further, such as local and inmigrant or older and younger business owners. The knock-on impacts of this in terms of their local embeddedness would also be interesting to explore. 
This study has only focused on positive impacts, and further work exploring the negative impacts of local businesses would be useful, again exploring differences across sectors, or businesses of different sizes, ages and ownership structures. These might include bringing in workers from outside the area on a temporary basis rather than employing local individuals, sourcing inputs from distant suppliers, and limited engagement in local community events. Such an exploration would lead to a much more holistic understanding of the positive and negative contributions of rural businesses.

Notwithstanding these suggestions for further research, this study has provided valuable data and analysis to substantially increase our knowledge about the contributions that rural business owners make to local community resilience in rural areas. Empirical data from rural South Australia has been combined with existing literature on embeddedness and the characteristics and motivations of rural entrepreneurs. It has drawn together currently disparate literature on different aspects of resilience, and demonstrated how rural businesses contribute in different ways to boosting the resilience of their local areas. It has argued that these broad contributions need to be recognised by policy-makers seeking to provide support for rural businesses, and seeking to enhance community resilience.

\section{APPENDICES}

Appendix 1 Example of interview questions

\begin{tabular}{|c|c|}
\hline Enquiry type & Example of questions \\
\hline Background information & $\begin{array}{l}\text { - What is the profile of your business? } \\
\text { - How many people do you employ? }\end{array}$ \\
\hline Networking & $\begin{array}{l}\text { Do you collaborate with other local businesses? How? Why? Give } \\
\text { examples. } \\
\text { Are there any other businesses with a similar profile in this region? Do } \\
\text { you collaborate or compete with them? Why? }\end{array}$ \\
\hline $\begin{array}{l}\text { Business and } \\
\text { Community }\end{array}$ & $\begin{array}{l}\text { - Does your business influence the life of local community? How? } \\
\text { - Can you identify benefits that your organisation brings to your local } \\
\text { community? Social/ Economic / Environmental? }\end{array}$ \\
\hline Local development & $\begin{array}{l}\text { - What is the role of your organisation in local development? } \\
\text { - What is a long term vision of your business? What is the potential impact } \\
\text { on the community? }\end{array}$ \\
\hline
\end{tabular}




\section{REFERENCES}

ABS (2010). Year Book Australia 2009-2010. Available at:

http://www.abs.gov.au/AUSSTATS/abs@.nsf/Lookup/047D4BA4016F7AOBCA25773700169C25?opendo cument (Accessed: 6 May 2013).

Acs, Z.J. \& Audretsch, D.B. (2003). Handbook of Entrepreneurship Research. Kluwer Academic Publishers, London.

Adger, N. (2000). Social and ecological resilience: are they related? Progress in Human Geography, 24(3), 347-364.

Adger, N. (2003). Social capital, collective action and adaptation to climate change. Economic Geography, 79, 387-404.

Aked, J., N. Marks, C. Cordon, \& Thompson, S. (2010). Five ways to wellbeing. The New Economics Foundation. Available at: http://neweconomics.org/projects/five-ways-well-being(Accessed: 6 May 2013).

Alberti, M. \& Marzluff, J. (2004). Ecological resilience in urban ecosystems: Linking urban patterns to human and ecological functions. Urban Ecosystems, 7, 241-265.

Aldrich, H. \& Zimmer, C. (1986). Entrepreneurship through social networks. In: D. Sexton and R. Smilor (eds.), The Art and Science of Entrepreneurship, Ballinger Publishing Co., New York, pp.3-23.

Anderson, A., Ossiechuk, E. \& Illingworth, L. (2009). Rural small businesses in turbulent times: impacts of the economic downturn. Paper presented at the 7th Rural Entrepreneurship Conference, Penrith (May).

Ateljevic, I. \& Doorne, S. (2000). Staying within the fence: lifestyle entrepreneurship in tourism. Journal of Sustainable Tourism 8 (5), 378-392.

Atterton, J. (2005). Networking in the Highlands and islands of Scotland: A Case Study of the Embeddedness of Firms in Three Small Towns, Unpublished PhD Thesis, University of Aberdeen.

Atterton, J. (2007). The 'Strength of Weak Ties': social networking by business owners in the Highlands and Islands of Scotland. Sociologia Ruralis, 47(3), 228-245.

Austin, J.E., Stevenson, H., \& Wei-Skillern, J. (2006). Social and Commercial Entrepreneurship: Same, Different, or Both? Entrepreneurship Theory and Practice, 30 (1), 1-22.

Australian Bureau of Statistics (2014). Census data comparison. Available at: http://www.abs.gov.au/ (Accessed 30.03.2014).

Australian Government (2011). Key Statistics, Australian Small Business, Department of Innovation, Industry, Science and Research. 
Australian Government (2014). Authoritative information and statistics to promote better health and wellbeing. Available at: https://www.aihw.gov.au/rural-health-remoteness-classifications/ (Accessed 30.03.2014).

Bengtsson, M. \& Kock, S. (2008). "Coopetition" in Business Networks - to Cooperate and Compete, Simultaneously Industrial Marketing Management, 29(5), 411-426.

Blumberg, B., Cooper, D. \& Schindler, P.S. (2005). Business research methods, McGraw-Hill Education, Berkshire.

Bonel, E., Pellizzari, P. \& Rocco, E. (2008). Coopetition and Complementarities: Modeling Coopetition Strategy and Its Risks at an Individual Partner Level, Management Research: Journal of the Iberoamerican Academy of Management, 6(3), 189-205.

Boshworth, G. (2012). Characterising rural businesses - Tales from the paperman. Journal of Rural Studies, 28, 499-506.

Bowles, P. (2000). Assessing the Impact of Proposed Bank Mergers on Rural Communities: A Case Study of British Columbia. Social Indicators Research, 51, 17-40.

Bruce, D. \& Halseth, G. (2004). The role of small business in community economic development. In G. Halseth and R. Halseth (Eds.) Building for Success: Exploration of Rural Community and Rural Development, Brandon, MB: Rural Development Institute, Brandon University. pp. 195-222.

Bruce, D. Ellis, K. \& Delury, N. (2006). The Role and Impact of Community Newsletters in Fostering Social Cohesion and Community Development. Journal of Rural and Community Development, 1 (2006), 176185.

Bryant, C. \& Joseph, A.E. (2001). Canada's rural population: trends in space and implications in place, The Canadian Geographer, 45(1), 132-137.

Bryman, A. \& Bell, E. (2007). Business Research Methods, Oxford University Press, Oxford.

Chell, E. \& Baines, S. (2000). Networking, entrepreneurship and microbusiness behaviour. Entrepreneurship and Regional Development, 12, 195-215.

Cloke, P., Crang, P., Goodwin,M., Painter, J. \&Philo, C. (2004). Practising Human Geography. London: Sage.

Courtney, P. \& Errington, A. (2000). The role of small towns in the local economy and some implications for development policy, Local Economy, 15, 280-301.

Credit Suisse Research Institute (2013). Global Wealth Reaches New All-Time High. The Financialist. Credit Suisse. Available at: http://www.thefinancialist.com/global-wealth-reaches-new-all-time-high/ (Accessed: 30.30.2014). 
Curran, J. \& Blackburn, R. (1994). Small Firms and Local Economic Networks: The Death of the Local Economy? Paul Chapman: London.

Dale, A. \& Onyx, J. (2005). A dynamic balance: social capital and sustainable community development, UBS Press, Vancouver.

Defra (2005). Defra Classification of Local Authority Districts and Unitary Authorities in England: an Introductory Guide. Developed by the Rural Evidence Research Centre, Birkbeck College, University of London.

Eachus, P. (2014). Community Resilience: Is it greater than the sum of the parts of individual resilience? Procedia Economics and Finance 18(2014), 345-351.

Farmer, J., Steinerowski, A. \& Jack, S. (2008). Starting social enterprises in remote and rural Scotland: best or worst of circumstances? International Journal of Entrepreneurship and Small Business, 6(3), 450464.

Folke, C. (2006). Resilience: the emergence of a perspective for social-ecological systems analyses. Global Environmental Change, 16 (3), 253-267.

Garnaut, J., Connell, P., Lindsay, R. \& Rodriguez, V. (2001). Country Australia: influences on employment and population growth. ABARE Research Report, 2001.1, Canberra.

Glover, J. (2012). Rural resilience through continued learning and innovation, Local Economy, 27(4), 355372.

Gorton, M. (1999). Spatial variations in markets served by UK-based small and medium-sized enterprises, Entrepreneurship and Regional Development, 11, 39-55.

Government of South Australia (2013). Economic Statement Government of South Australia, Government of South Australia.

Granovetter, M. (1985). Economic action and social structure: the problem of embeddedness, American Journal of Sociology, 91(3), 481-510.

Granovetter, M. (2005). The Impact of Social Structure on Economic Outcomes, The Journal of Economic Perspectives, 19(1), 33-50.

Gray, D. E. (2004). Doing Research in the Real World. London: SAGE Publications.

Halseth, G. \& Ryser , L. (2006). Trends in service delivery: Examples from rural and small town Canada, 1998 to 2005. Journal of Rural and Community Development, 1 (2006), 69-90.

Hegney, D., H. Ross, P. Baker, C. Rogers-Clark, C. King, E. Buikstra, A. Watson-Luke, K. McLachlan, \& L. Stallard. (2008). Building Resilience in Rural Communities. The University of Queensland and University of Southern Queensland. 
Heley, J. \& Jones, L. (2012). Relational rurals: Some thoughts on relating things and theory in rural studies. Journal of Rural Studies 28, 208-217.

Herbert-Cheshire, L. \& Higgins, V. (2004) From risky to responsible: expert knowledge and the governing of community-led rural development, Journal of Rural Studies, 20, 289-302.

Herbert-Cheshire, L. (2000) Contemporary strategies for rural community development in Australia: a governmentality perspective, Journal of Rural Studies, 16, 203-215.

Hingley, M., Custance, P. \& Walley, K. (2006). Coopetition within the UK AgriFood chain In Bijman, J., Omta, O., Trienekens, J.,Wubben, E., and Wijnands, J. (Eds.), 7th International Conference on Management in AgriFood Chains and Networks, 31 May - 2 June, Department of Business Administration, Wageningen University. Wageningen Academ.

Hird, M.J. (2003). Case Study, in R.L. Miller and J.D. Brewer, (eds) A-Z of Social Research, SAGE Publications, London.

Hofferth, S. \& Iceland, J. (1998). Social capital in urban and rural communities, Rural Sociology, 63(4), 574-598.

Jack, S., \& Mouzas, S. (2007). Entrepreneurship as renegotiated exchange in networks. Paper presented at the 23rd IMP Conference: Exploiting the b-to-b knowledge network: new perspectives and core concepts, Manchester, UK.

Jack, S.L. \& Anderson, A.R. (2002). The effects of embeddedness on the entrepreneurial process, Journal of Business Venturing, 17(1), 467-488.

Kay, A. (2003). Social capital in building the social economy. In: J. Pearce (ed.), Social Enterprise in Anytown, Calouste Gulbenkian Foundation, London, 72-83.

Kilpatrick, S., Johns, S., Vitartas, P., Homisan, M. (2011). Mobile skilled workers: Making the most of an untapped rural community resource, Journal of Rural Studies, 27(2011), 181-190.

Kitchin, R. \&Tate, N. (2000). Conducting research into human geography: theory, methodology \& practice. London: Prentice Hall.

Leach, K. (2013). Community economic development: Localisation, the key to a resilient and inclusive local economy? Local Economy, 1-5.

Magis, K. (2010). Community resilience: an indicator of social sustainability. Society and Natural Resources, 33(5), 401-416.

Marsden, T. (1999). Rural futures: The consumption countryside and its regulation. Sociologia Ruralis, 39, 501-520.

Martz, D. \& Sanderson, K. (2006). The Economic and Social Contribution of the Public Sector to Rural Saskatchewan. Journal of Rural and Community Development, 1 (2006), 91-113. 
Mazzarol, T., Reboud, S. \& Volery, T. (2010). The influence of size, age and growth on innovation management in small firms. International Journal of Technology Management, 52(1-2), 98-117.

McDaniel, K. (2001). Small Business in Rural America. The Main Street Economist. (May) www.kc.frb.org. Center of the Study of Rural America. Federal Reserve Bank of Kansas City.

McManus, P., Walmsley, J., Argent, N., Baum, S,. Bourke, L., Martin, J, Pritchard, B., Sorensen, T. (2012). Rural Community and Rural Resilience: What is important to farmers in keeping their country towns alive? Journal of Rural Studies, 28, 20-29.

McMorran, R., Scott, A.J., Price, F.P. (2014). Restructuring sustainability; participant experiences of community land tenure in North West Scotland, Journal of Rural Studies, 33(2014), 20-31.

Milman, A. \& Short, A. (2008). Incorporating resilience into sustainability indicators: An example for the urban water sector. Global Environmental Change, 18(1),758-767.

Morrison, T.H., Wilson, C., \& Bell, M. (2012). The role of private corporations in regional planning and development: Opportunities and challenges for the governance of housing and land use. Journal of Rural Studies 28, 478-489.

Mort, G.S., Weerawardena, J., \& Carnegie, K. (2002). Social entrepreneurship: towards conceptualisation, International Journal of Nonprofit and Voluntary Sector Marketing, 8, 76-88.

Murray, M. \& Dunn, L. (1995) Capacity building for rural development in the United States, Journal of Rural Studies, 11(1), 89-97.

Nalebuff, B.J. \& Brandenburger, A.M. (1997). Co-opetition: Competitive and cooperative business strategies for the digital economy, Strategy \& Leadership, 25(6), 28-33.

Norris, F., Stevens, S., Pfefferbaum, B., Wyche, K. \& Pfefferbaum, R. (2008). Community Resilience as a Metaphor, Theory, Set of Capacities, and Strategy for Disaster Readiness. American Journal of Community Psychology, 41, 127-150.

Noya, A. \& Clarence, E. (2009). Community capacity building: fostering economic and social resilience. CFE/LEED, OECD.

OECD. (2014). Community Resilience documents. Available at: http://www.oecd.org/general/searchresults/?q=community\%20resilince (Accessed: 7 November 2014).

Oinas, P. (1997) On the socio-spatial embeddedness of business firms, Erdkunde, 51, 23-32.

Onyx, J., Leonard, R. (2005) Australian Grey Nomads and American Snowbirds: Similarities and differences. The Journal of Tourism Studies, 16(1), 61-67.

Oughton. E.A., Wheelock, J. \& Baines, S. (2003). Micro-businesses and social inclusion in rural households: A comparative analysis. Sociologia Ruralis, 43(4), 331-348. 
Pendall, R., Foster, K.A. \& Cowell, M. (2010). Resilience and regions: Building understanding of the metaphor. Cambridge Journal of Regions, Economy and Society, 3(1), 71-84.

Phillipson, J., Bennett, K., Lowe, P. \& Raley, M. (2004). Adaptive responses and asset strategies: the experience of rural micro-firms and Foot and Mouth Disease. Journal of Rural Studies, 20(2), 227-243.

Plodinec, M.J., Edwards, W.C., White, R.K. (2014). Applications of a "Whole Community" Framework for Enhancing Community or Campus Resilience, Procedia Economics and Finance 18 (2014), 9-16.

Plunkett Foundation (2011). Be Inspired. Update from the Plunkett Community Shop Network. Available at: http://www.plunkett.uk.net/be-inspired (Accessed 09.04.14.).

PricewaterhouseCooper (2007). The economic contribution of small to medium-sized grocery retailers to the Australian economy with particular focus on Western Australia, National Association of Retailers Grocers of Australia, Sydney.

Reimer, B. (2006). The rural context of community development in Canada. Journal of Rural and Community Development , 1 (2006), 155-175.

Roberts, D., \& Woods, C. (2005). Changing the world on a shoestring: the concept of social entrepreneurship. University of Auckland Business Review, 7, 45-51.

Rola-Rubzen, M.F. (2011). The Anatomy of the Australian Entrepreneur: Understanding micro, small and medium business entrepreneurs in Australia. Ninti One Limited. Alice Springs. Available at: http://www.nintione.com.au/resource/NintiOneReport AnatomyoftheAustralianEntrepreneur.pdf (Accessed: 6 May 2013).

Sarason, Y., Dean, T. \& Dillard, J.F. (2006). Entrepreneurship as the nexus of individual and opportunity: a structuration view, Journal of Business Venturing, 21(3), 286-305.

Saunders, M.N.K., Lewis, P. \& Thornhill, A. (2003). Research Methods for Business Students, $3^{\text {rd }}$ ed., Financial Times Prentice Hall, London.

Schouten, M.A.H., Martijn van der Heide, C., Heijman, W.J.M., Opdam, P.F.M (2012). A resilience-based policy evaluation framework: Application to European rural development policies, Ecological Economics, 81(2012), 165-175.

Schutt, R. (2012). Investigating the Social World, SAGE, London.

Scottish Government (2012). Rural Scotland Key Facts 2012. People and Communities, Services and Lifestyle, Economy and Enterprise. A National Statistics Publication for Scotland, Edinburgh.

Shane, S., \& Venkataraman, S. (2000). The Promise of Entrepreneurship as a Field of Research. The Academy of Management Review, 25(1), 217-226.

Shucksmith, M., Chapman, P., Clark, G.M., Black, J.S. \& Conway, E. (1996). Rural Scotland Today: The Best of Both Worlds? Ashgate Publishing Limited, Aldershot. 
Skerratt, S. \& Steiner, A. (2013). Working with communities-of-place: complexities of empowerment. Local Economy, 28(3), 320-338.

Skerratt, S. (2013) Enhancing the analysis of rural community resilience: Evidence from community land ownership. Journal of Rural Studies, 31, 36-46.

Smailes, P.J., Argent, N. \& Griffin, T.L.C. (2002). Rural population density: its impact on social and demographic aspect of rural communities, Journal of Rural Studies, 385-404.

Smith, R. (2008). Zzz. Some reflections on the dynamics of village entrepreneurship. International Journal of Entrepreneurship and Small Business, 6(3), 370-389.

Steiner, A. \& Atterton, J. (2014). The contribution of rural businesses to community resilience, Local Economy, 29(3), 219-235.

Steiner, A. \& Cleary, J. (2014). What are the features of resilient businesses? Exploring the perception of rural entrepreneurs. Journal of Rural Community and Development, 9(3), 1-20.

Steiner, A. \& Markantoni, M. (2014). Exploring Community Resilience in Scotland through Capacity for Change. Community Development Journal, 49(3), 407-425.

Steinerowski, A. \& Steinerowska-Streb, I. (2012). Can social enterprise contribute to creating sustainable rural communities? Using the lens of structuration theory to analyse the emergence of rural social enterprise. Local Economy, 27(2), 167-182.

Steinerowski, A., Jack, S. \& Farmer, J. (2008a). Social entrepreneurship in a rural context: an overideological state? Journal of Rural Enterprise and Management, 4(1), 20-39.

Steinerowski, A., Jack, S. \& Farmer, J. (2008b). Who are the social entrepreneurs and what do they actually do? Frontiers of Entrepreneurship Research, 693-708.

Taylor, R. Forrester, J., Pedoth, L., Matin, N. (2014). Methods for integrative research on community resilience to multiple hazards, with examples from Italy and England, Procedia Economic and Finance, 18(2014), 255-262.

Thomas, D.R. (2006). A general inductive approach for analyzing qualitative evaluation data. American Journal of Evaluation 27,237-246.

Uzzi, B. (1996). The sources and consequences of embeddedness for the economic performance of organisations: the network effect, American Sociological Review, 61, 674-98.

Valentine,G. (2005). Tell me about...: using interviews as a research methodology. In: R. Flowerdew and D. Martin (eds.) Methods in Human Geography: A Guide for Students Doing a Research Project, $2^{\text {nd }}$ ed., Prentice Hall, Harlow, 110-126.

Walley, K. \& Custance. P. (2010). Coopetition: insights from the agri-food supply chain, Journal on Chain and Network Science, 10(3), 185-192. 
Wilding, N. (2011). Exploring Community Resilience in Times of Rapid Change, Carnegie UK Trust, Dunfermline.

Williams, C.C. (2007). Socio-spatial variations in the nature of entrepreneurship. Journal of Enterprising Communities, 1(1), 27-37.

Wilson, G. A. (2012). Community Resilience and Environmental Transitions, London: Routledge.

Woods, M. (2003). Deconstructing rural protest: the emergence of a new social movement. Journal of Rural Studies 19(3), 309-325.

Woods, M. (2007). Engaging the global countryside: globalization, hybridity and the reconstitution of rural place. Progress in Human Geography 31(4), 485-507.

Woods, M. (2008). Guest editorial: social movements and rural politics. Journal of Rural Studies 24(2), 129-137.

Woods, M. (2011). Rural. Routledge, Abingdon.

World Bank (2014). The World Bank, Data, Australia, Available at:

http://data.worldbank.org/country/australia (Accessed: 09.04.2014).

\section{ACKNOWLEDGEMENTS}

This research was undertaken as part of the Scottish Government's Strategic Research Programme 'Governance and decision-making for community empowerment' 2011-2016 and co-funded through SRUC's International Engagement Fund. The authors would like to thank all study participants for their participation, and all those who facilitated the study including Regional Development Australia and University of South Australia. Special thanks to Dr Jen Cleary and Sian Ringrose for her invaluable comments on and support for this paper. Finally, sincere thanks to the journal editor and two anonymous reviewers for providing valuable and extensive feedback on an earlier draft of this paper. 